\section{Expression of lumican and fibromodulin following interleukin-1 beta stimulation of disc cells of the human temporomandibular joint}

\author{
N. Kiga, I. Tojyo, T. Matsumoto, \\ Y. Hiraishi, Y. Shinohara, S. Makino, \\ S. Fujita
}

Department of Oral and Maxillofacial Surgery, Wakayama Medical University, Japan

\section{Abstract}

Small leucine-rich repeat proteoglycans (SLRP) are present in the extracellular matrix of the temporomandibular joint (TMJ) disc. Lumican and fibromodulin, classified as class 2 SLRPs, play important roles in TMJ assembly, proliferation and inflammation. Degenerative change in the TMJ disc gives rise to the process of internal derangement (ID). In this study, we immunohistochemically examined the expression of lumican and fibromodulin in nine human TMJ specimens and examined the gene expression of both proteoglycans in cultured human TMJ disc cells under interleukin1 beta (IL-1 $\beta$ )-stimulated conditions. An articular disc cell line was established by collagenase treatment of a TMJ disc. The subcultured cells were then incubated for $1,3,6,12,24$ or $48 \mathrm{~h}$ under both normal and IL-1 $\beta$ ( $1 \mathrm{ng} / \mathrm{mL})$ conditions. The gene expression of lumican and fibromodulin was examined using the reverse transcription-polymerase chain reaction (RT-PCR) and real-time RT-PCR. We demonstrated that the expression of lumican significantly differs from that of fibromodulin in the deformed disc and that IL- $1 \beta$ induces a significant increase in lumican mRNA, but not in fibromodulin mRNA, after $24 \sim 48$ h culture compared to cells cultured in the absence of IL$1 \beta(\mathrm{P}<0.05)$. These results indicate that lumican and fibromodulin display different behaviors and that lumican may promote regeneration of the TMJ after degeneration and deformation induced by IL-1 $\beta$.

\section{Introduction}

Recent studies have showed the pathological changes of human temporomandibular joint (TMJ) discs affected by internal derangement (ID)..$^{1,2}$

The extracellular matrix in the articular disc of TMJ is composed mainly of collagen, gly- cosaminoglycans (GAGs) and proteoglycans. ${ }^{3,4}$ Furthermore, proteoglycan (decorin, biglycan, fibromodulin) mRNA has been reported to be expressed in TMJ discs. ${ }^{5}$ We previously reported that the proteoglycan lumican is expressed in human TMJ discs and that it is strongly expressed in deformed discs. ${ }^{6}$ Lumican and fibromodulin are class 2 small leucine-rich repeat proteoglycans (SLRPs) that contain primarily keratan sulfate, and their respective genes have a similar exonic organization (three exons), with a large central exon encoding most of the leucine-rich repeats (LRRs). ${ }^{7}$ Recent studies have shown that lumican is also expressed in tissues such as the cornea, the intervertebral disc and in tendons and that it plays a significant role in the assembly and regulation of collagen fibers. ${ }^{8-13}$ Lumican that is expressed in injured epithelium is reported to modulate cell behavior such as adhesion or migration, thereby contributing to corneal epithelial wound healing. ${ }^{14}$ Gene expression analysis by cDNA array and RT-PCR demonstrated higher lumican mRNA levels in scoliotic discs vs. normal discs. ${ }^{15}$ Fibromodulin has been reported to be expressed in a number of tissues, including the epidermis, intervertebral discs, tendons, and the TMJ disc. ${ }^{16-19}$ Growth, aging, and degeneration of the intervertebral disc are associated with changes in the abundance and structure of fibromodulin and lumican. ${ }^{11}$

Internal derangement of TMJ is a progressive disorder with an abnormal anatomic relationship of the TMJ disc to the mandibular condyle, articular eminence and glenoid fossa. The process of ID of TMJs is caused by cytokines [interleukin-1 beta (IL-1 $\beta$ ), TGF- $\beta$, TNF- $\alpha$ ], trauma, functional overloading, joint laxity, lack of lubrication or hyperactivity of the lateral pterygoid muscle. The TMJ deformed disc is considered to cause the degeneration and deformation that occurs during the

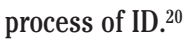

Recent studies showed that IL-1 $\beta$ is predominantly localized in synovial lining cells and in the endothelial cells of blood vessels..$^{21-24}$ Furthermore, IL-1 $\beta$ is secreted not only from synovial membranes but also from activated macrophages and from a variety of other cell types and elicits many biological responses, including thymocyte proliferation, wound healing, and tissue resorption. ${ }^{25}$ Therefore, IL-1 $\beta$ may play a particularly important role in the process of ID. The aim of this study was to compare the expression of lumican and fibromodulin in the deformed disc and to analyze a role for IL-1 $\beta$ in the regulation of these proteins in cultured human TMJ disc cells.

We therefore compared the protein expression of lumican and fibromodulin in deformed discs of TMJ using immunohistochemical staining and analyzed the effect of IL-1 $\beta$ stim-
Correspondence: Norifumi Kiga, Department of Oral and Maxillofacial Surgery, Wakayama Medical University, 811-1 Kimiidera, Wakayama 641-8509, Japan. Tel/Fax: +81.73.441.0643. E-mail: kibun@wakayama-med.ac.jp

Key words: lumican, fibromodulin, IL-1 beta, temporomandibular joint disc, small leucine-rich repeat proteoglycan.

Received for publication: 22 November 2010. Accepted for publication: 22 February 2011.

This work is licensed under a Creative Commons Attribution 3.0 License (by-nc 3.0).

(C) Copyright N. Kiga et al., 2011

Licensee PAGEPress, Italy

European Journal of Histochemistry 2011; 54:e11 doi:10.4081/ejh.2011.e11

ulation on the gene expression of lumican and fibromodulin in cultured human TMJ disc cells using the polymerase chain reaction (PCR).

\section{Materials and Methods}

\section{Immunohistochemical analysis}

Nine TMJ discs were investigated (Table 1). The patients' ages ranged from 20 to 72 years, with a mean age of 49.8 years. We treated the patients using conservative treatment, and only carried out open surgery on patients for whom conservative treatment was unsuccessful. All discs were macroscopically deformed, and none of the discs had a normal biconcave shape. We evaluated the nine TMJ discs using the histopathological degeneration grading score system. All nine TMJ discs displayed a severe grade of degeneration. ${ }^{26}$ The patients did not have a history of trauma to the mandible, and none of them had ankylosis. All the patients gave complete informed consent for the surgery and the use of their tissue in the research, which was approved by the Human Reserch Ethics Committee, Wakayama Medical University.

The specimens were fixed overnight in $4 \%$ paraformaldehyde, embedded in paraffin wax, and cut to obtain 5-um-thick sections. For immunohistochemical staining, the sections were dewaxed in xylene and rehydrated in serial alcohol. Endogenous peroxidase was blocked by immersing the sections in $0.3 \%$ $\mathrm{H}_{2} \mathrm{O}_{2}$ in methanol for 20 min at room temperature. The specimens were blocked with $3 \%$ skimmed milk [0.01\% Tween-phosphatebuffered saline (PBS)] for $60 \mathrm{~min}$ at room temperature and were then treated using rabbit polyclonal antibodies against lumican 
(Wakayama Medical University, Wakayama, Japan) and fibromodulin (University of South Florida, Tampa, FL, USA) at $4^{\circ} \mathrm{C}$ for $12 \mathrm{~h}$. The anti-lumican and the anti-fibromodulin polyclonal antibodies were used at a dilution of 1:800 and 1:400. After washing with PBS, the specimens were treated with horseradish peroxidase-labelled anti-rabbit IgG antibody (Dako, Glostrup, Denmark) for $60 \mathrm{~min}$ at room temperature. The colour was developed using 3,3'-diaminobenzidine/ $\mathrm{H}_{2} \mathrm{O}_{2}$ solution followed by counterstaining with Mayer's hematoxylin. The negative controls were subjected to the same protocol except that PBS was used instead of the primary antibody.

\section{Cultivation of temporomandibular joint disc cells}

Cell culture of TMJ disc tissue obtained from a patient with synovial osteochondromatosis was performed as follows. The patient provided informed consent, and the study was approved by the Ethics Committee of Wakayama Medical University. Thin sections of the disc tissue were cut and immersed in $0.25 \%$ trypsin and $0.25 \mathrm{mM}$ EDTA (Gibco-BRL, Life Technologies Inc., Grand Island, NY, USA) for 20 min followed by collagenase (Roche Diagnostics, Mannheim, Germany) treatment for $3 \mathrm{~h}$. The tissues were then washed with Dulbecco's modified Eagle's medium (DMEM) (Gibco-BRL, San Francisco, CA, USA) containing $10 \%$ fetal bovine serum (FBS) (EquitechBio Inc., Kerrville, TX, USA) and 1\% penicillin/streptomycin (Gibco-BRL). The cells were grown at $37^{\circ} \mathrm{C}$ in a humidified $5 \% \mathrm{CO}_{2}$ atmosphere, and were passaged every 14 days. All experiments were carried out on cells at passage 5 .

The cell culture and IL-1 treatment protocols used in this study were validated in a previous study. ${ }^{27}$ In brief, the cells were plated at a density of $1 \times 10^{6}$ /well in 6-well plates (Iwaki, Asahi Techno Glass, Funabashi, Japan) in the above $10 \%$ FBS-containing medium. Once the cells became confluent, the medium was changed to serum-free medium and the cells were incubated for $24 \mathrm{~h}$. The cultures were rinsed with phosphate-buffered saline (PBS), and then 2 $\mathrm{mL}$ of fresh serum-free medium, with or without $1 \mathrm{ng} / \mathrm{mL}$ of IL-1 $\beta$ (PeproTech, London, UK) was added, and the cells were incubated for a further $1,3,6,12,24$ or $48 \mathrm{~h}$ in a humidified atmosphere of $20 \% \mathrm{O}_{2}, 5 \% \mathrm{CO}_{2}$ and $75 \% \mathrm{~N}$.

\section{Reverse transcription-polymerase chain reaction}

Total RNA was isolated from the cultured cells using an RNeasy ${ }^{\circledR}$ Mini Kit (Qiagen, Valencia, CA, USA). The first strand cDNA was synthesized from $0.5 \mu \mathrm{g}$ of total RNA using
SuperScript ${ }^{\circledR} \quad$ transcriptase (Invitrogen, Carlsbad, CA, USA). The reactions were primed with Oligo (dT) 12-18 primers and the total volume was $20 \mu \mathrm{L}$. RT-PCR analysis was performed in a total volume of $50 \mu \mathrm{L}$ using Taq. DNA polymerase (Ampli Taq Gold ${ }^{\circledR}$, Applied Biosystems, Foster City, CA, USA) and $1 \mu \mathrm{L}$ of the cDNA sample as a template. PCR amplification was performed for 35 cycles (denaturation: $95^{\circ} \mathrm{C}$ for $30 \mathrm{~s}$; annealing: $60^{\circ} \mathrm{C}$ for $60 \mathrm{~s}$; extension: $72{ }^{\circ} \mathrm{C}$ for $120 \mathrm{~s}$ ). Table 2 shows the primer sequences used for this study. The PCR products were electrophoresed on a $2 \%$ agarose gel and were visualized following ethidium bromide staining using a densitometer (Atto, Tokyo, Japan). All experiments were performed three times.

\section{Real-time polymerase chain reaction}

Total RNA was isolated from TMJ disc cells using the RNeasy ${ }^{\circledR}$ Mini Kit (Qiagen), as described in the protocol provided with the kit. First-strand cDNA was synthesized from $1 \mu \mathrm{g}$ of total RNA using the SuperScript ${ }^{\circledR}$ transcriptase (Invitrogen). The reactions were primed with Oligo (dT) primers and the total volume was $20 \mu \mathrm{L}$. RT-PCR was performed using the BIO-RAD iCycler iQ system (Bio Rad, Hercules, CA, USA) according to the manufacturer's instructions. The reactions were performed in a total volume of $50 \mu \mathrm{L}$ using the iQ SYBR Green Supermix (Bio Rad); 0.5 $\mu \mathrm{L}$ of cDNA sample was used as a template. Cycling was started with an activation step at $95^{\circ} \mathrm{C}$ for 3 min, and the amplification program was repeated 45 times (denaturation: $95^{\circ} \mathrm{C}$ for $15 \mathrm{~s}$; annealing: $60^{\circ} \mathrm{C}$ for $30 \mathrm{~s}$; extension: $72^{\circ} \mathrm{C}$ for $30 \mathrm{~s}$ ) with fluorescence measurement at $72^{\circ} \mathrm{C}$. All samples were run in triplicate with the internal control [18S ribosomal RNA (18S rRNA)] and the target gene (Table 2) on the same plate. The fluorescence threshold value was calculated using the iCycle iQ system software version $3.0 \mathrm{~A}$. To confirm amplification specificity, the PCR products from each primer pair were subjected to a melting curve analysis. Real-time PCR efficiencies for each reaction were calculated using the formula Efficiency $(E)=10^{[-1 / \text { slope }]}$, from the slope values given in the iCycle $\mathrm{iQ}$ system software. The $\Delta \mathrm{Ct}$ values for the reference gene (18S rRNA) and the target gene were calculated by subtracting the value of the experimental group (normal or IL-1 $\beta$-treated). The mathematical model presented by Pfaffl was used to determine the relative quantification of the target gene in comparison to the reference gene. The relative expression ratio ( $R$ ) of the target gene was calculated based on $\mathrm{E}$ and the $\Delta \mathrm{C}_{\mathrm{t}}$ of the experimental group versus the control, and is expressed in comparison to $18 \mathrm{~S}$ rRNA.

\section{Statistical analysis}

All values are expressed as the means of

Table 1. Clinical data of patients.

\begin{tabular}{|c|c|c|c|c|c|c|}
\hline $\begin{array}{l}\text { Sample } \\
\text { no. }\end{array}$ & Sex & Age & $\begin{array}{c}\text { Diagnosis } \\
\text { (years) }\end{array}$ & Symptom & $\begin{array}{l}\text { Mouth max } \\
\text { (pain) }\end{array}$ & $\begin{array}{c}\text { Displacement of } \\
\text { opening ( } \mathrm{mm} \text { ) } \\
\text { TMJ disc }\end{array}$ \\
\hline 1 & Female & 20 & $\mathrm{ID}-\mathrm{OA}$ & + & 32 & + \\
\hline 2 & Female & 58 & ID - OA & + & 45 & + \\
\hline 3 & Female & 52 & $\mathrm{ID}-\mathrm{OA}$ & + & 25 & + \\
\hline 4 & Male & 72 & $\mathrm{ID}-\mathrm{OA}$ & + & 18 & + \\
\hline 5 & Female & 72 & $\mathrm{ID}-\mathrm{OA}$ & + & 39 & + \\
\hline 6 & Male & 64 & ID - OA & - & 37 & + \\
\hline 7 & Female & 52 & $\mathrm{ID}-\mathrm{OA}$ & + & 30 & + \\
\hline 8 & Female & 24 & $\mathrm{ID}-\mathrm{OA}$ & + & 15 & + \\
\hline 9 & Female & 34 & $\mathrm{ID}-\mathrm{OA}$ & - & 20 & + \\
\hline
\end{tabular}

TMJ, temporomandibular joint; ID, internal derangement; OA, osteoarthritis.

Table 2. Details of polymerase chain reaction primers used in the present study.

\begin{tabular}{|c|c|c|}
\hline Gene & Accession no. & Primer \\
\hline Fibromodulin & NM_002023 & $\begin{array}{c}\text { F, 5' -GGGGCAAGGACTGTTGGAGGAG-3' } \\
\text { R, 5' -CCAGGTCTGGAGCC-3' }\end{array}$ \\
\hline Lumican & U21128 & $\begin{array}{l}\text { F, 5' -CCACCACACCTGACAGAGT-3' } \\
\text { R, 5' -CAAGTTGATTGACCTCCAGG-3' }\end{array}$ \\
\hline 18S rRNA & BX296557 & $\begin{array}{l}\text { F, 5' -GTTGGTGGAGCGATTTGTCT-3' } \\
\text { R, 5' -GGCCTCACTAAACCATCCAA-3' }\end{array}$ \\
\hline
\end{tabular}


three experiments \pm S.D. The statistical significance was evaluated using one-way ANOVA. P-values less than 0.05 were considered significant. Satistical analysis was performed using Excel X for Mac (Microsoft, Redmond, WA, USA) with the add-in softwave Statcel 2 (OMS, Tokyo, Japan).

\section{Results}

\section{Immunohistochemical analysis of lumican and fibromodulin in deformed temporomandibular joint discs}

We first compared the protein expression of lumican and fibromodulin in the deformed discs using immunohistochemistry. The discs did not have a normal biconcave shape (Figure $1 \mathrm{~A})$. Fibromodulin was expressed in areas of weak lumican expression (Figure $1 \mathrm{~B}, \mathrm{C}$ ) and was also expressed adjacent to the area of strong lumican expression (Figure 1 D,E). Strong lumican expression was observed over a large area of the disc surface (Figure $1 \mathrm{~F}$ ). Fibromodulin expression was localized slightly below the disc surface (Figure $1 \mathrm{G}$ ).

\section{The effect of IL-1 $\beta$ treatment on lumican and fibromodulin expression in temporomandibular joint cells}

To evaluate the potential contribution of lumican and fibromodulin to TMJ disc disruption during inflammation, we evaluated the effect of IL-1 $\beta$ treatment of TMJ cells on the mRNA expression of lumican and fibromodulin. Their mRNA expression was assayed using RT-PCR (Figure 2) and was quantified using real-time PCR (Figure 3) following incubation with $1 \mathrm{ng} / \mathrm{mL}$ IL-1 $\beta$ over 48 h. IL-1 $\beta$ induced a significant increase in lumican mRNA after 24 48 h incubation compared to the level in cells grown in the absence of IL-1 $\beta$ $(\mathrm{P}<0.05)$. There were no significant changes in the gene expression of fibromodulin in the presence or absence of IL-1 $\beta$ (Figures 2, 3).

\section{Discussion}

In the present study, we performed both in vitro and in vivo studies of the TMJ disc. We have shown that, although both lumican and fibromodulin are expressed in the deformed TMJ disc, IL-1 $\beta$ enhances lumican, but not fibromodulin mRNA expression. It is known that lumican and fibromodulin compete for the same binding sites on collagen fibrils of ECM and that fibromodulin has higher affinity for these sites than lumican. ${ }^{28}$ Ezura et al. have proposed that developmental stage-specific functions are mediated by differential expression patterns of lumican and fibromodulin. ${ }^{29}$ Thus, lumican expression decreases to barely detectable levels during the progression of fibrillogenesis, whereas fibromodulin expression significantly increases during this process. In another study, it was reported that the immunostaining intensity of lumican had increased in the migrating epithelium 3 days after wounding, whereas the staining intensity of fibromodulin was reduced in the migrating epithelium. However, in that study, the staining intensity of fibromodulin was gradu-
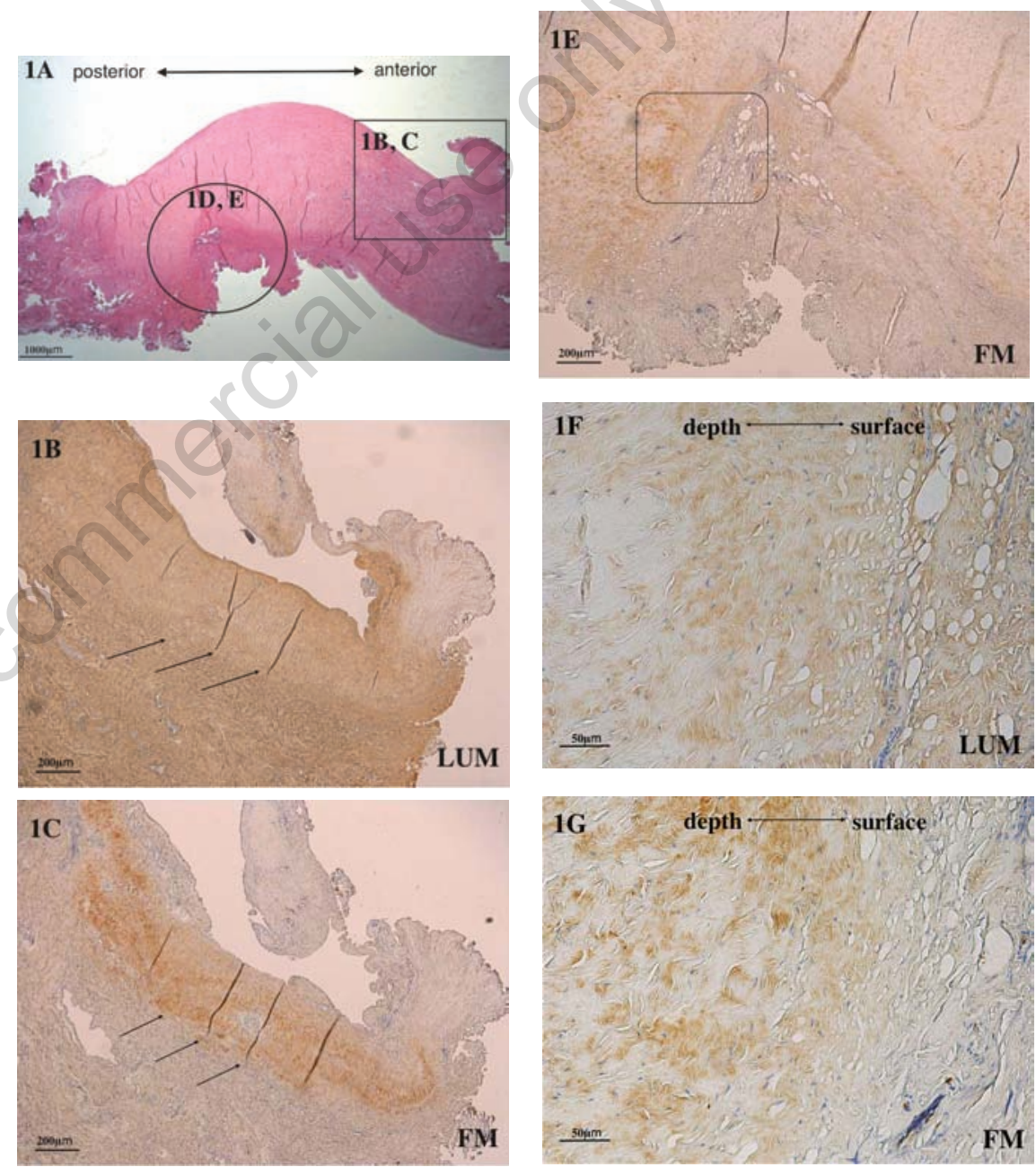

Figure 1. Immunohistochemical analysis of Lumican (LUM) and fibromodulin (FM) expression in the deformed disc. (A) Hematoxylin and eosin stain of the deformed TMJ disc. (B) Strong lumican expression and weak lumican expression (arrows) in the deformed part of the disc (enlargement of the circle in Figure 1 A). (C) Localized fibromodulin expression at sites of weak lumican expression (arrows) (enlargement of the rectangle in Figure $1 \mathrm{~A}$ ). (D) Strong lumican expression in the deformed part of the disc. (E) Fibromodulin expression in the deformed part of the disc. (F) High power of the boxed region in the lumican-stained panel $D$. (G) High power of the boxed region in the fibrobmodulin-stained panel E (scale bars: A, $1000 \mu \mathrm{m}$; B-E, $200 \mu \mathrm{m} ; \mathrm{F}$ and $\mathrm{G}, 50 \mu \mathrm{m}$ ). 
Lumican

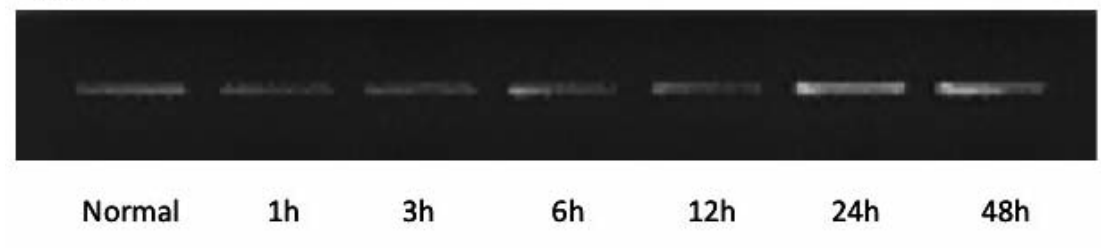

Fibromodulin

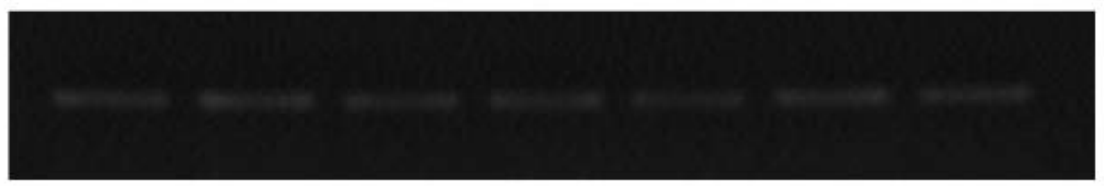

Normal

$1 \mathrm{~h}$

3h

$6 \mathrm{~h}$

$12 \mathrm{~h}$

$24 \mathrm{~h}$

$48 \mathrm{~h}$

18S rRNA

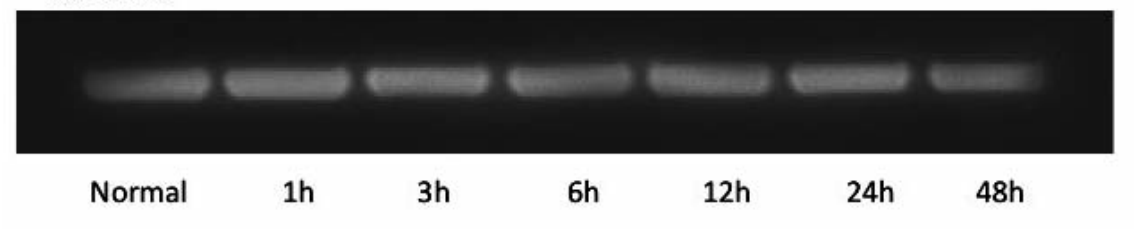

Figure 2. Effect of IL-1 $\beta$ on the gene expression of lumican and fibromodulin. RT-PCR was performed to evaluate the effect of $1 \mathrm{ng} / \mathrm{mL}$ IL- $1 \beta$ on the mRNA expression of lumican and fibromodulin in cultured TMJ cells over a period of 1 to $48 \mathrm{~h}$. Control represents culture for $48 \mathrm{~h}$ in the absence of IL-1 $\beta$.
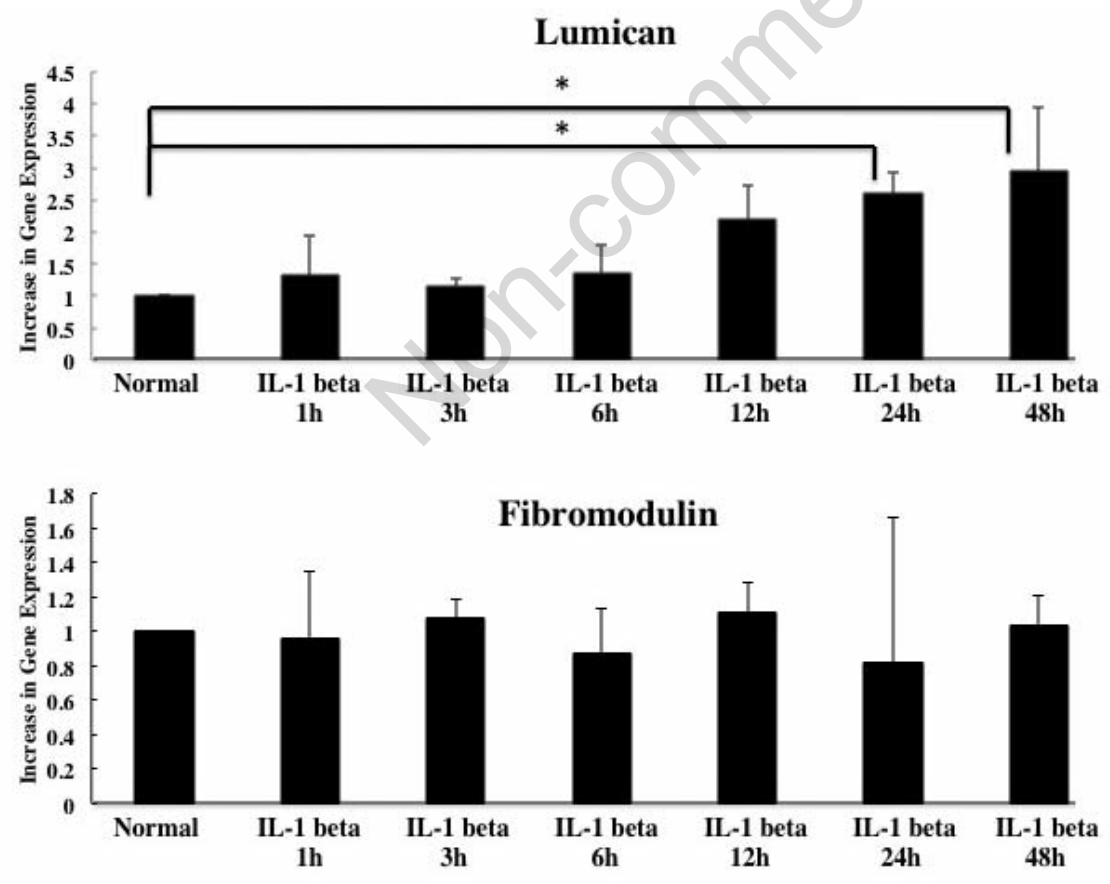

Figure 3. Quantification of the effect of IL-1 $\beta$ on the gene expression of lumican and fibromodulin. The effect of 48 -h culture with $1 \mathrm{ng} / \mathrm{mL}$ of IL-1 $\beta$ on the mRNA expression of lumican (A) and fibromodulin (B) was quantified using the real-time polymerase chain reaction (RT-PCR). The mRNA expression at each time point is expressed as fold-change compared to normal cells that were cultured in the absence of IL-1 for $48 \mathrm{~h}$. Asterisks denote significant differences $(P<0.05)$.
However, $\mathrm{Clq}$ binds to an $\mathrm{N}$-terminal fragment of fibromodulin and this binding has been suggested to play a role in IL-1 stimulation of cartilage. Fibromodulin that is a component of cartilage has the ability to activate an inflammatory cascade, i.e., complement. ${ }^{32}$ Therefore, lumican and fibromodulin may function in different processes that are involved in cellular adjustment to a changed external environment such as extracellular matrix assembly, proliferation and inflammation. Based on previous reports in other systems, it is likely that lumican mRNA will show a gradual decrease, and fibromodulin mRNA will show an increase, or no change, if IL-1 $\beta$ stimulation of cultured human TMJ disc cells is extended for a much longer time than the time used in this study. However, this possibility remains to be experimentally confirmed. Our data suggest that lumican, but not fibromodulin, may function in the rapid adjustment of TMJ cells to a change in the environment, especially to changes due to inflammation. However, it cannot be excluded that fibromodulin levels may increase, and play a role, at later stages of this adjustment. In conclusion, we have shown that lumican and fibromodulin are differentially expressed in the deformed TMJ disc. Although lumican and fibromodulin mRNA are both expressed under IL-1 $\beta$-stimulated conditions in cultured human TMJ disc cells, the level of lumican mRNA, but not that of fibromodulin mRNA, is enhanced by IL-1 $\beta$. These findings suggest that lumican and fibromodulin are differentially regulated and that lumican may promote regeneration of the TMJ following the degeneration and deformation induced by IL-1 $\beta$.

\section{References}

1. Matsumoto T, Inayama M, Tojyo I, Kiga N, Fujita S. Expression of hyaluronan synthase 3 in deformed human temporomandibular joint discs: in vivo and in vitro studies. Eur J Histochem 2010;54:e50.

2. Loreto C, Almeida LE, Migliore MR, Caltabiano M, Leonardi R. TRAIL, DR5 and caspase 3-dependent apoptosis in vessels of diseased human temporomandibular joint disc. An immunohistochemical study. Eur J Histochem 2010;54:e40.

3. Piacentini C, Marchetti C, Bernasconi G, Menghini P, Baciliero U, Brusotti C. Collagen fiber arrangement in temporomandibular joint (TMJ) disks from human subjects with functional diseases. Scanning electron microscopy investigations. Scanning Microsc 1994;8:207-13.

4. Benjamin M, and Ralphs JR. Biology of fibrocartilage cells. Int Rev Cytol 2004;233: $1-45$. 
5. Paegle DI, Holmlund A, Hjerpe A. Expression of proteoglycan mRNA in patients with painful clicking and chronic closed lock of the temporomandibular joint. J Oral Maxillofac Surg 2005;34:656-8.

6. Kiga N, Tojyo I, Matsumoto T, Hiraishi Y, Shinohara Y, Fujita S. Expression of lumican related to CD34 and VEGF in the articular disc of the human temporomandibular joint. Eur J Histochem 2010;54:e34.

7. Schaefer L, Iozzo RV. Biological functions of the small leucine-rich proteoglycans: From genetics to signal transduction. J Biol Chem 2008;283:21305-9.

8. Scott JE. Supramolecular organization of extracellular matrix glycosaminoglycans, in vitro and in the tissues. FASEB 1992;6:2639-45.

9. Funderburgh JL, Funderburgh ML, Brown SJ, Vergnes JP, Hassell JR, Mann MM, et al. Sequence and structural implications of a bovine corneal keratan sulfate proteoglycan core protein. J Biol Chem 1993;268: 11874-80.

10. Svensson L, Aszodi A, Reinholt FP, Fassler R, Heinegard D, Oldberg A. Fibromodulinnull mice have abnormal collage fibrils, tissue organization, and altered lumican deposition in tendon. J Biol Chem 1999; 274:9636-47.

11. Sztrolovics R, Alini M, Mort JS, Roughley PJ. Age-related changes in fibromodulin and lumican in human intervertebral discs. Spine 1999;24:1765-71.

12. Gill MR, Oldberg A, Reinholt FP. Fibromodulin-null murine knee joints display increased incidences of osteoarthritis and alterations in tissue biochemistry. Osteoarthritis Cartilage 2002;10:751-7.

13. Raouf A, Ganss B, McMahon C, Vary C, Roughley PJ, Seth A. Lumican is a major proteoglycan component of the bone matrix. Matrix Biol 2002;21:361-7.

14. Saika S, Shiraishi A, Saika S, Lin CW, Funderburgh JL, Kao CW, et al. Role of lumican in the corneal epithelium during wound healing. J Biol Chem 2000;275:2607-12.

15. Bertram H, Steck E, Zimmerman G, Chen B, Carstens C, Nerlich A, et al. Accelerated intervertebral disc degeneration in scolio- sis versus physiological ageing develops against a background of enhanced anabolic gene expression. Biochem Biophys Res Commun 2006;342:963-72.

16. Melrose J, Smith SM, Fuller ES, Young AA, Roughley PJ, Dart A, et al. Biglycan and fibromodulin fragmentation correlates with temporal and spatial annular remodeling in experimentally injured ovine intervertebral discs. Eur Spine J 2007;16: 2193-205.

17. Vélez-Delvalle $\mathrm{C}$, Marsch-Moreno $\mathrm{M}$, Castro-Muñozledo F, Bolivar-Flores YJ, Kuri-Harcuch W. Fibromodulin gene is expressed in human epidermal keratinocytes in culture and in human epidermis in vivo. Biochem Biophys Res Commun 2008;371:420-4.

18. Embree MC, Kilts TM, Ono M, Inkson CA, Syed-Picard F, Karsdal MA, et al. Biglycan and fibromodulin have essential roles in regulating chondrogenesis and extracellular matrix turnover in temporomandibular joint osteoarthritis. Am J Pathol 2010;176: 812-26.

19. Kilts T, Ameye L, Syed-Picard F, Ono M, Berendsen $\mathrm{AD}$, Oldberg A, et al. Potential roles for the small leucine-rich proteoglycans biglycan and fibromodulin in ectopic ossification of tendon induced by exercise and in modulating rotarod performance. Scand J Med Sci Sports 2009;19:536-46.

20. Nitzan DWD. The process of lubrication impairment and its involvement in temporomandibular joint disc displacement: a theoretical concept. J Oral Maxillofac Surg 2001;59:36-45.

21. Suzuki T, Segami N, Kanetama K, Nishimura M, Nojima T. Specific expression of interleukine-1 $\beta$ in temporomandibular joint with internal derangement. Oral Surg Oral Med Oral Pathol Oral Radiol Endod 1999;88:413-17.

22. Yoshida H, Fujita S, Nishida M, Izuka T. Angiogenesis in the human temporomandibular joint studied by immunohistochemistry for CD34 antigen. J. Oral Pathol Med 1999;28:289-92.

23. Yoshida H, Fujita S, Nishida M, Izuka T. Localization of lymph capillaries and blood capillaries in human temporomandibular joint discs. J Oral Rehabil 1999;26:600-7.

24. Leonardi R, Lo Muzio L, Bernasconi G, Caltabiano C, Piacentini C, Caltabiano M. Expression of vascular endothelial growth factor in human dysfunctional temporomandibular joint discs. Arch Oral Biol 2003;48:185-92.

25. Ito A, Mukaiyama A, Itoh $\mathrm{Y}$, Nagase $\mathrm{H}$, Thogersen IB, Enghild JJ, et al. Degradation of interleukin 1beta by matrix metalloproteinases. J Biol Chem 1996;271:14657-60.

26. Leonardi R, Rusu MC, Loreto C. Temporomandibular joint disc: a proposed histopathological degeneration grading score system. Histol Histopathol 2010;25: 1117-22.

27. Matsumoto T, Tojyo I, Kiga N, Hiraishi Y, Fujita S. Expression of ADAMTS-5 in deformed human temporomandibular joint discs. Histol Histopathol 2008;23:1485-93.

28. Svensson L, Närlid I, Oldberg A. Fibromodulin and lumican bind to the same region on collagen type I fibrils. FEBS Lett 2000;470:178-82.

29. Ezura Y, Chakravarti S, Oldberg A, Chervoneva I, Birk DE. Differential expression of lumican and fibromodulin regulate collagen fibrillogenesis in developing mouse tendons. J Cell Biol 2000;151:779-88.

30. Honardoust D, Eslami A, Larjava H, Häkkinen L. Localization of small leucinerich proteoglycans and transforming growth factor- $\beta$ in human oral mucosal wound healing. Wound Repair Regen 2008;16:814-23.

31. Westergren-Thorsson G, Antonsson P, Malmström A, Heinegård D, Oldberg A. The synthesis of family of structurally related proteoglycans in fibroblasts is differently regulated by TGF- $\beta$. Matrix 1991; 11:177-83.

32. Sjöberg A, Onnerfjord P, Mörgelin M, Heinegård D, Blom AM. The extracellular matrix and inflammation: fibromodulin activates the classical pathway of complement by directly binding Clq. J Biol Chem 2005;280:32301-8. 